\title{
Testnevelö tanárjelölt hallgatók vizsgálata a pályaválasztásról alkotott véleményük tükrében \\ PE teacher candidates' examination in the mirror of their opinion formed about the choice of career
}

\author{
Uhlár Ádám ${ }^{[1]}$, Szemes Ágnes ${ }^{[2]}$, Tóth László[3] \\ 1 TE, Osztatlan tanár szakos hallgató, uhlaradam56@gmail.com \\ 2 TE, Pszichológia és Sportpszichológia Tanszék, oktató és PhD. hallgató, agnes.szemes@tf.hu \\ 3 TE, Pszichológia és Sportpszichológia Tanszék, egyetemi docens, Itoth@tf.hu
}

\begin{abstract}
Absztrakt: Kutatásunk célja, hogy megvizsgáljuk egy budapesti egyetem testneveló tanárképzésének egyes évfolyamait és felmérjük a hallgatók különbözó motivációs tényezóit, a képzésról alkotott véleményüket, valamint a diploma megszerzését követő terveiket. A pedagógusi pálya választásakor szerepet játszó motivációs tényezők közül kiemelkedó a tanári hivatástudat, a tantárgyakkal szembeni pozitív attitűd, illetve egy-egy korábbi tanár befolyásoló hatása is (Simon, 2006; Chrappán, 2010). A képzés során és azt követó néhány évben azonban nagymértékú lemorzsolódás, pályaelhagyás figyelhető meg (Varga, 2007; Sági \& Varga, 2011). A kutatás idején a pedagógusképzési rendszerben már viszszaállították az osztatlan tanári képzést, így lehetőségünk adódott összehasonlítani azt a BSc képzéssel, mivel azok egyes évfolyamokon párhuzamosan múködnek. A vélemények feltérképezéséhez saját összeállítású kérdőívet használtunk, melyet összesen 107 hallgató töltött ki. Eredményeink alapján elmondható, hogy a tanári pálya iránti elköteleződésnél eróteljesebb motivációs tényezó a tantárgy iránti, jelen esetben a sport iránti szeretet, továbbá sok az elégedetlenség a képzéssel kapcsolatban. Ennek ellenére a hallgatók közel fele hosszú távon a tanári pályán szeretne elhelyezkedni. Találtunk több szignifikáns összefüggést a képzési formák és az évfolyamok között is, melyek mélyebb feltárása, okainak felderítése segítséget adhat a pedagógusképzés formálásához.
\end{abstract}

Kulcsszavak: motiváció, pedagógusképzés, tanári pályán eltölteni kívánt idó

\begin{abstract}
The aim of the research is to assess motivation factors of PE teacher trainees studying at different programmes and years of a university in Budapest. The survey also asks their opinions about the training and their plans after graduation. From among the factors the sense of vocation, the positive attitude towards the subjects and the influence of a former teacher are of great importance (Simon, 2006; Chrappán, 2010). But during the training and a few years after their graduation a large-scale dropout and career change can be observed (Varga, 2007; Sági \& Varga, 2011). During the research the undivided teacher training programme was already restored so it was possible to compare its curriculum to those of the BSc and MSc training programmes as they existed parallel to each other. The applied self-prepared questionnaire focusing on motivations of career choice and evaluation of PE teacher training programmes were filled in by 107 students. Based on the results it can be said that love for the subject, in this case for sports is a stronger motivation than the commitment to the teacher's work. On the other hand there is dissatisfaction with the teacher training programme. In spite of this nearly half of the students want to find a job as a PE teacher in the long run. Significant correlations were also found between the forms and years of training. A further and more thorough exploration of these causes may help the reconstruction of teacher training programmes.
\end{abstract}

Keywords: career motivation, PE teacher training, perspectives of a PE teacher 


\section{Bevezetés}

A pályaválasztás és a szakirány választás olyan döntési helyzetet takar, mikor az egyénnek két vagy több pálya lehetőség közül kell egyet megjelölnie, melyen tovább halad (Szilágyi, 1993). Völgyesy (1976) szerint a közvetlen környezetet, a társadalmi hatásokat és a korábbi személyes tapasztalatokat csak megfelelő előkészítéssel képes a fiatal integrálni és ez alapján megfelelően választani. A környezet információs szintje nagymértékben befolyásolja a döntés lehetséges alternatíváinak számát. Minél kevesebb információt tud az egyén, pl. rendelkezik-e a megfelelő ismeretekkel, vannak-e elképzelései a választott szakmáról, annál nagyobb valószínűséggel választ spontán, véletlenül, esetleg kényszerből, és ez által kevésbé lesz sikeres a döntése. A megfelelő döntés meghozatalához tehát elengedhetetlenek bizonyos személyes és külső tartalmi elemek/feltételek megléte. Kutatások igazolják, hogy az érdeklődés, mint belső motiváció nagyobb szerepet kap a pályaorientációban, mint a képességek megléte, de koránt sincs akkora hatással, mint az egyéni értékrendszer (Szilágyi, 1997). A munkamód és a tanulási stílus ismerete szintén meghatározóak, hiszen nem mindegy hogyan szereti az ember elvégezni és megoldani a feladatát, illetve miképpen tud a legjobban tanulni. A tanulás során pedig nemcsak ismereteket gyüjt az egyén, és fejleszti a képességeit, hanem megismerését, gondolkodásmódját, szemléletét és ítélőképességét is alakítja (Szilágyi, 2000). A társadalmi környezet ismeretéhez tartozik a jogi és közgazdasági információkon túl a pályaismeret is, mely abban segíti az egyént, hogy máshogyan is lássa a lehetőségeit, amikor a megfelelő pályát keresi (Rókusfalvy, 1969). Továbbá tisztában kell lenni a munkaerö-piaci lehetőségekkel is, hiszen fontos, hogy az iskolából kilépők képzettsége és a munkaerő-piaci kereslet egymáshoz illeszkedjen (Dávid, 2005). A magyar képzési rendszer felépítése három egymásra épülő ciklusból áll, mely több továbbképzési lehetőséget biztosít, és ezzel együtt időt hagy a személyes tényezők felismerésére is (Kenderfi, 2011).

A felsorolt tényezők közvetve, vagy közvetlenül is befolyást gyakorolhatnak a pályaválasztásra, némelyek erősen képesek behatárolni a lehetőségeket, mások viszont változóképesek, ezáltal új megoldásmódokat ajánlhatnak (Girasek, 2013). A hallgatók a képzés ideje alatt jobban megismerik a választott pályát és reflektálnak a társadalmi aspektusaira is (életmód, várható jövedelem, munkaidő, stb). A többség olyan munkát szeretne, amelynek van jövője, biztonságos és jó pénzkereseti lehetőséget nyújt. Az elérhető kutatási eredmények alapján elmondható, hogy a legfőbb választási motiváció szakmai természetű, mint például a szakmai és tudományos kihívások és ezt követik az olyan társadalmi tényezők, mint a jövedelem, munkaterhelés és presztízs, de nem elhanyagolható a hallgató neme sem (Soethout et. al., 2008; Nieuwhof et. al., 2005, Lefevre et. al., 2010, áttekinti Szemes, 2016).

A pedagóguspálya választásában szerepet játszó motivációs tényezők Simon (2006) kutatási eredményei alapján négy fö faktorba sorolhatók: könynyed egyetemi lét (intézmény lakóhelyhez való közelsége, barátokkal való együtt maradás, elegendő felvételi pontszám, könnyű diplomaszerzés, társadalmi elvárásnak való megfelelés), tantárggyal szemben kialakult pozitív attitűd (pozitív minták, induló szakirány, érdeklődés, tanultak gyakorlati hasznosíthatósága), önfejlesztési igény (képességek tökéletesítése, tanulási tevékenység kedvelése, személyiségfejlesztő hatás), felnőtt személy befolyásoló hatása (család, tanári indíttatás). Más vizsgálati eredmény is rávilágít arra, hogy a pedagóguspálya választásában számos motivációs tényező jelentősen közrejátszik. A tudományterület iránti érdeklődés mellett megjelenik a tanított korosztály szeretete, a pedagóguspálya iránti elköteleződés, az intézmény hozzáférhetősége és a diáklét folytatásának vágya is (Nagy, 2001). Chrappán (2010) kutatási eredménye alapián a felsorolt tényezők közül a hivatástudat miatti választás a legerőteljesebb, Lukács (2002) szerint viszont a hallgatók csupán egy ötödére jellemző ez az elhivatottság, és idővel az anyagi megfontolások egyre gyakrabban felülírják ezt a szerepvállalást. A tanári kereset ugyanis a folyamatos béremelések ellenére is még mindig kevésnek számít, függetlenül az iskolatípustól (Brezsnyánszky, 2006). Ezt a folyamatot nevezi Varga (2007) negatív önszelekciós hatásnak. Sági és Varga (2011) felmérése igazolja, hogy a pedagógusdiplomával rendelkezők több mint 60 \%-a nem a pedagóguspályán helyezkedik el, és a kevésbé jó képességüek töltik be legnagyobb valószínűséggel a tanári állásokat. Testnevelés és sport műveltségterületi képzést választó tanítók esetében a sportolás szeretete, az egészséges élettel kapcsolatos elköteleződés és a szelf-determinált viselkedés is szerepet játszott a pályaválasztásánál (Spittle, Jackson \& Casey, 2009, 
áttekinti Szemes, 2016; Spittle \& Spittle, 2014).

A lemorzsolódást magyarázhatja az is, hogy a tanárképzést követően a gyakorlatban számtalan olyan helyzettel szembesülnek a pályakezdő tanárok, ahol gyorsan és önállóan kell döntést hozniuk és melyre nem tanultak megfelelö módszertant (Falus, 2006). Ilyenkor többnyire spontán módon reagálnak, olyan megoldásmódokat használnak, melyeket korábban tanáraiktól láttak, tapasztaltak. A gyakorlatban tehát, függetlenül attól milyen képesítéssel végeztek tanulmányaikkal, a képzés során elsajátított ismereteket nem alkalmazzák. Nehezen tudják a megszerzett tudást adekvát módon beilleszteni, különösen a szokásostól eltérő nevelési helyzetekben. A képzés során ugyanis nincs alkalmuk a gyakorlatba kellően beépíteni és elmélyíteni a pszichológiai és pedagógiai ismereteket (Sallai, 2001).

Számos empirikus kutatás alapián állítható, hogy a képzésbe lépő tanárjelöltek - más szakokat választókkal szemben - a korábbi személyes és iskolai tapasztalataik nyomán kialakult, a képzés szempontjából releváns, a tanári szakmával és a saját személyiségükkel kapcsolatos nézetrendszerrel és rengeteg ismerettel rendelkeznek a választott pályájukkal kapcsolatban (Buchmann, 1984; Clark, 1988; Floden, 1985; Nespor, 1987; Pajares, 1992; Weinstein, 1989). E nézetek legfontosabb tulajdonsága az, hogy a tanári szakma tanulásakor szűrőként funkcionálnak és befolyásolják a képzés eredményességét. Meghatározzák, hogy a hallgatók mit tanulnak meg a képzésből és azt is, hogy később hogyan fognak tanítani; pozitívan vagy negatívan viszonyulnak-e a tanárképzési programokhoz; mit és milyen mértékben sajátítanak el tanulmányaik során; hogyan értelmezik a helyzeteket, hogyan közelítik meg a képzési tartalmakat (Britzman, 1991; Calderhead, 1996; Falus, 1992; Goodman, 1988; Johnston, 1994). Ha nem történik meg a hallgatói nézetek feltárása, szükség esetén a módosítása, akkor hatástalan maradhat a képzésben közvetíteni kívánt tudás is (Dudás, 2005).

Laczkovich (2009) szerint a Bologna-rendszer tanárképzésének felépítése sajnos nem megfelelő erre, hiszen a kredit-centrikusság érzéketlen a szakmai tartalomra, továbbá a két szakdolgozat megírása energia és időpocsékolás is egyben. „Olyan pedagógusképzésre van szükség, amely lehetőséget ad a hallgatóknak arra, hogy felszínre hozzák, tudatosítsák - többnyire nem tudatos - belépő nézeteiket, egy viszonylag korszerű gyakorlathoz kapcsolódóan, valamint külső forrásokból (elöadások, szakirodalom, személyes tapasztalatcserék) származó ismeretek felhasználásával megformálják saját, személyes gyakorlati pedagógiai tudásukat, amely lehetővé teszi számukra az iskolai oktató-nevelő munka eredményes ellátását, valamint e munka folyamatos reflexiója, kutatói szemléletű megközelítése által a folyamatos szakmai fejlődést" (Falus, 2002, 73.).

A tanárrá válás folyamata tehát a képzésbe lépés előtt elkezdődik és a képzés elvégzése után is folytatódik. Berliner (2005) egy ötszakaszos tanári életpálya modellt írt le, melyet véleménye szerint nem minden tanár jár végig. A szakismeretek, készségek, szakmai hozzáértés és illetékesség elérésével felkészülten vágnak neki a tanári tevékenységnek az újoncok. A pályán tapasztalt első sikerek és kudarcok nagyban befolyásolják hogyan éli meg a pályakezdő a tanári létet, a pályán marad vagy elhagyja azt (Nagy, 2004). Huberman, Groundauer \& Marti (1993) a túlélés és felfedezés éveinek nevezi az első pár évet. A következő szakaszok a középhaladó, majd a kompetens tanár, ahol a kontextusok közti hasonlóság felismerhetővé válik és racionális döntést képes hozni az egyén. A jártas és szakértői szintre azonban kis létszám jut el, mely teljes körü rálátást és komplex sémarendszert igényel, hogy a feladatokra igényesebb, tanításban alkalmazkodóbb és rugalmasabb megoldást adjanak.

\section{Célkitüzés}

A vizsgált budapesti egyetem pedagógusképzési rendszere a kutatás idején már visszaállította az osztatlan tanári képzést, így egyes évfolyamokon párhuzamosan működik a BSc-vel. Kutatásunk célja, hogy felmérjük az egyes évfolyamok és képzési szakok közti különbségeket, a motivációs tényezők, a képzésről alkotott vélemények, valamint a képzés elvégzését követő tervek kapcsán. A válaszok feltérképezéséhez kérdőívet használtunk, hogy lehetőségünk nyíljon különböző dimenziók együttes vizsgálatára is.

\section{Hipotézisek}

1. A pedagóguspályára történő jelentkezéskor többféle motivációs tényező is szerepet játszik, nem emelkedik ki a tanári hivatástudat szerepe (Lukács, 2002; Nagy, 2001). 
2. A hallgatók az első években leginkább a képzés mennyiségi jellegével, majd a végzést megelőző években a képzés minőségi jellegével elégedetlenebbek, így az intézmény megítélése is negatívá válhat. Mennyiségi jelző az oktatott tantárgyak száma, az elméleti órákra fordított idő, míg minőségi jelzőnek számít a felkészítés mértéke, mely a gyakorlatokban, pedagógusi és pszichológia készségek fejlesztésében nyilvánul meg (Lukács, 2004; Kocsis, 2003).

3. A tanárjelöltek többsége nem pedagógus pályán szeretne a végzést követően elhelyezkedni (Varga, 2007; Sági \& Varga, 2011).

4. Az évfolyamok közti különbségeken felül feltételezhető, hogy az osztott és az osztatlan tanár szakos hallgatók között is megjelennek eltérések (Laczkovich, 2009; Falus, 2002).

\section{Módszerek}

Vizsgálatunkban összesen 107 testnevelő tanárképzésre járó hallgató vett részt, 52 férfi és 55 nő, akiket online kérdőív segítségével vizsgáltunk meg. $\mathrm{Az}$ újonnan indított osztatlan testnevelő tanár szak 1. évfolyamáról 29 fö (9 férfi, 20 nő), 2. évfolyamáról 15 fơ ( 9 férfi, 6 nő) vett részt. Az osztott képzésben tanulók közül a BSc szak utolsó indított évfolyamáról, azaz a 2. évfolyamról 28 fó (14 férfi, 14 nő), 3. évfolyamról 22 fö (13 férfi, 9 nő), míg MSc. testnevelő tanár szakról, melyen 13 fö (7 férfi, 6 nő) vett részt. A vizsgálati személyek 18 és 26 év közöttiek voltak ( $M=21,49$ év; $S=1,91$ év).

A vizsgálathoz saját összeállítású kérdőívet készítettünk és használtunk. A létrehozott kérdőív összesen 10 kérdésből állt (érintett témakörök: jelentkezési motiváció, jövőbeli tervek, tanári pályán eltölteni kívánt idő, tanári pálya megítélése, képző intézmény megítélése, képzéssel való elégedettség mértéke), 3 demográfiai adatra vonatkozó kiegészítéssel.

A vizsgálati személyeknek az volt a feladatuk, hogy a nemük, életkoruk és évfolyamuk megnevezése után a feltett kérdésekre online feleletválasztós teszt formájában, illetve 5 fokú Likert skálán megjelöljék az önmagukra leginkább vonatkozó választ. A kérdőív átlagosan 5 percet vett igénybe és teljesen anonim volt.

\section{Eredmények}

A normalitás-vizsgálat elvégzésével elmondható, hogy a Kolmogorov-Smirnov teszt értéke alapján nem homogének a személyek válaszai $(\mathrm{p}=0,001)$, a csúcsosság és a ferdeség is pozitív értéket vesz fel, tehát nem követik a normál eloszlást, így nem használhattunk paraméteres próbákat a későbbi számításokhoz. A hallgatók eredményeit így MannWhitney és Kruskal-Wallis próbával valamint nemparaméteres korrelációval vizsgáltuk meg.

Az első hipotézis teszteléséhez az egész mintára vonatkozóan vizsgáltuk meg a jelentkezési motivációkat (lásd. 1. ábra). A testnevelő tanári pálya választásakor a legdominánsabb tényező erőteljes belső motiváltságra utal. Legtöbben a sport iránti szeretet (60 fö) miatt jelentkeztek, ezt követi a tanári hivatástudat miatti választás (23fó). A gyerekekkel való foglalkozás szeretete (3 fó) ennél jóval kevésbé jelentős. A többieket leginkább olyan külső tényezők motiváltak, mint a munkahely által biztosított, állandó szociális kapcsolati háló (8 fó) és a változatos munkavégzés ( 8 fó), vagy hatottak rájuk különböző felnőtt minták, esetleg teljesen spontán választottak ( 5 fó).

A jelentkezési motivációkat továbbá összehasonlítottuk az egyes évfolyamok és a kétféle képzési rendszerben hallgatók között is. Ehhez az öt évfolyam hallgatóit külön választottuk osztatlan (44 fó) és osztott (63fö) képzési rendszerben tanulók csoportjára. Szignifikáns különbség egyedül a sport iránti szeretet kapcsán mutatkozott $\left(\chi^{2}(4)=13,090\right.$; $\mathrm{p}=0,011)$, mely a BSc második és harmadik évfolyamos hallgatóira jellemző motivációs tényező. Összehasonlítva a képzési formákat, szignifikánsan magasabb a sport iránti szeretetből adódó motivációja az osztott képzésre járó hallgatóknak $(\mathrm{U}=1072,5 ; \mathrm{Z}=-2,357 ; \mathrm{p}=0,018)$ a jelentkezéskor (lásd. 2. ábra).

A második hipotézis teszteléséhez a hallgatók képzéssel való elégedettségének mértékét és az intézményről kialakult képet vizsgáltuk meg az ott eltöltött idő függvényében. A megkérdezettek közül csupán 25-en elégedettek és nem csalódtak semmiben a képzéssel kapcsolatban. A többség az oktatási rendszerrel elégedetlen ( 40 fö), ezt követi a gyakorlatokkal (24 fö) illetve a tanárokkal kapcsolatos elégedetlenség (11 fö). Legkevésbé az elméleti órákban (1 fö) és egyéb tényezőkben (6 fö) csalódtak a hallgatók (lásd. 3. ábra). 


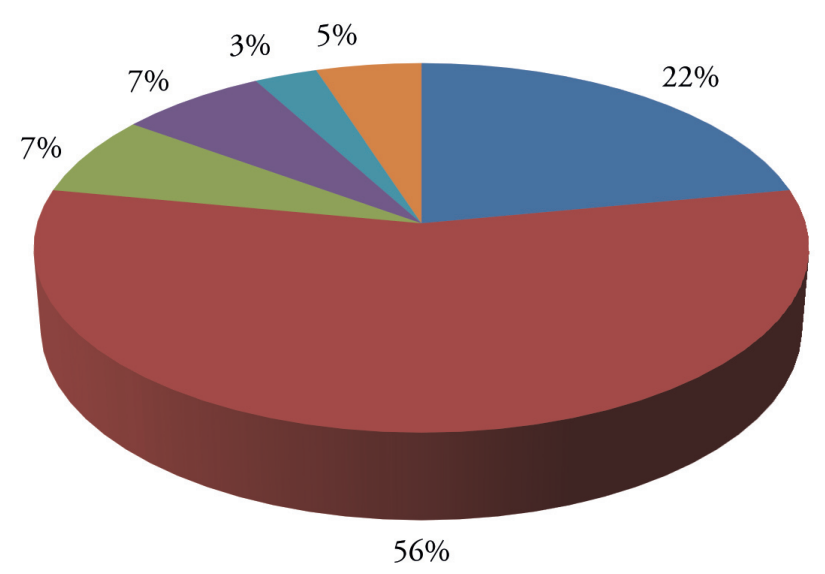
- Tanári hivatástudat
Sport iránti szeretet
Állandó szociális közeg
- Változatos, szórakoztató munkavégzés
- Gyerekekkel való foglalkozás szeretete
Egyéb (családi minta követése, spontán választás)

1. ábra: A hallgatók testnevelő tanár szakra való jelentkezését befolyásoló tényezők százalékos megoszlása

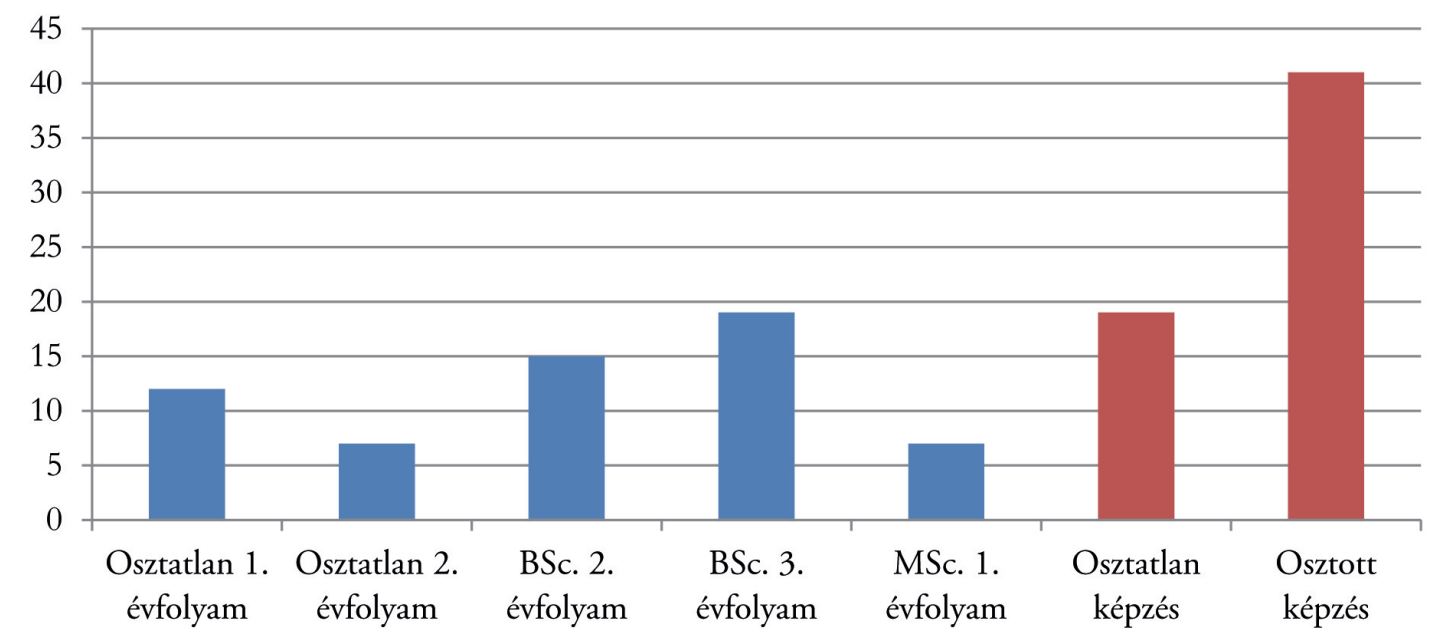

2. ábra: Évfolyamok és képzési formák sport iránti szeretete

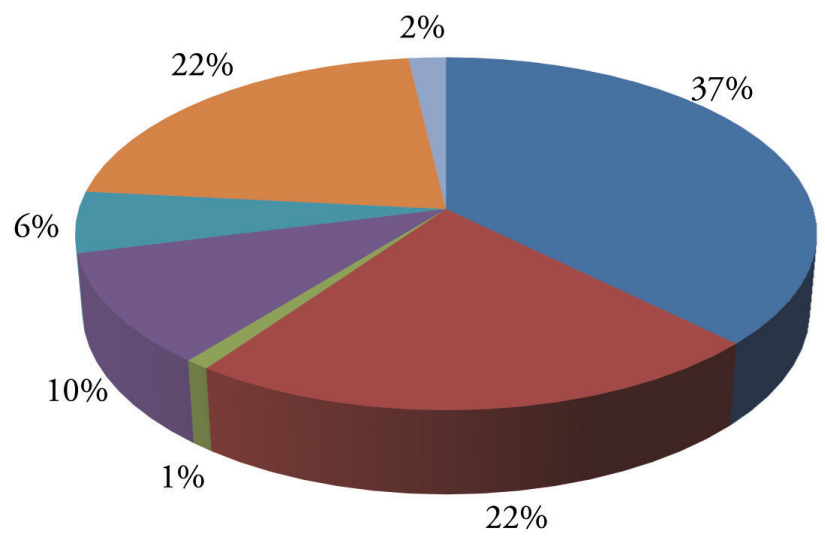

— Csalódtam az oktatásban

- Csalódtam a gyakorlatok mennyiségében

- Csalódtam az elméleti órák mennyiségében

- Csalódtam a tanárokban

Csalódtam egyéb dolgokban (légkör, feladatok)

- Nem csalódtam

- Segített rájönni mi a nekem való szakma

\section{3. ábra: A hallgatói elégedettség mértékének százalékos megoszlása}


A képző intézményről kialakított vélemény tekintetében a hallgatók 61,7 \%-a a vizsgálat szerint nem azt kapta, amit várt, 29,9\% volt, aki nem csalódott és elégedett, $8,4 \%$ pedig még többet is kapott, mint amit remélt az intézménytől.

Az évfolyamok között szignifikáns a képzéssel való elégedettség $\left(\chi^{2}(4)=11,44 ; \mathrm{p}=0,022\right)$ és az intézmény megítélése $\left(\chi^{2}(4)=15,224 ; \mathrm{p}=0,004\right)$ közti különbség is. Az oktatásban leginkább a BSc 2. évfolyamosok csalódtak, míg a gyakorlatok számával legkevésbé a mester szakosok elégedettek. A tanárokban és az elméleti órák mennyiségében a BSc. 3. évfolyamosok csalódtak leginkább. A képzéssel összességében az osztatlan 1. évfolyamosok vannak legjobban megelégedve (lásd. 4. ábra). Az intézmény megítélését tekintve a BSc 2. és 3. évfolyamosok vélik leginkább úgy, hogy nem azt kapták, amit vártak, az osztatlan 1. és 2 . évfolyamosok viszont igen, sőt közöttük nagyobb számban gondolják úgy, hogy többet kaptak, mint amit reméltek és ugyanez igaz a mester szakos hallgatókra is (lásd. 5. ábra).

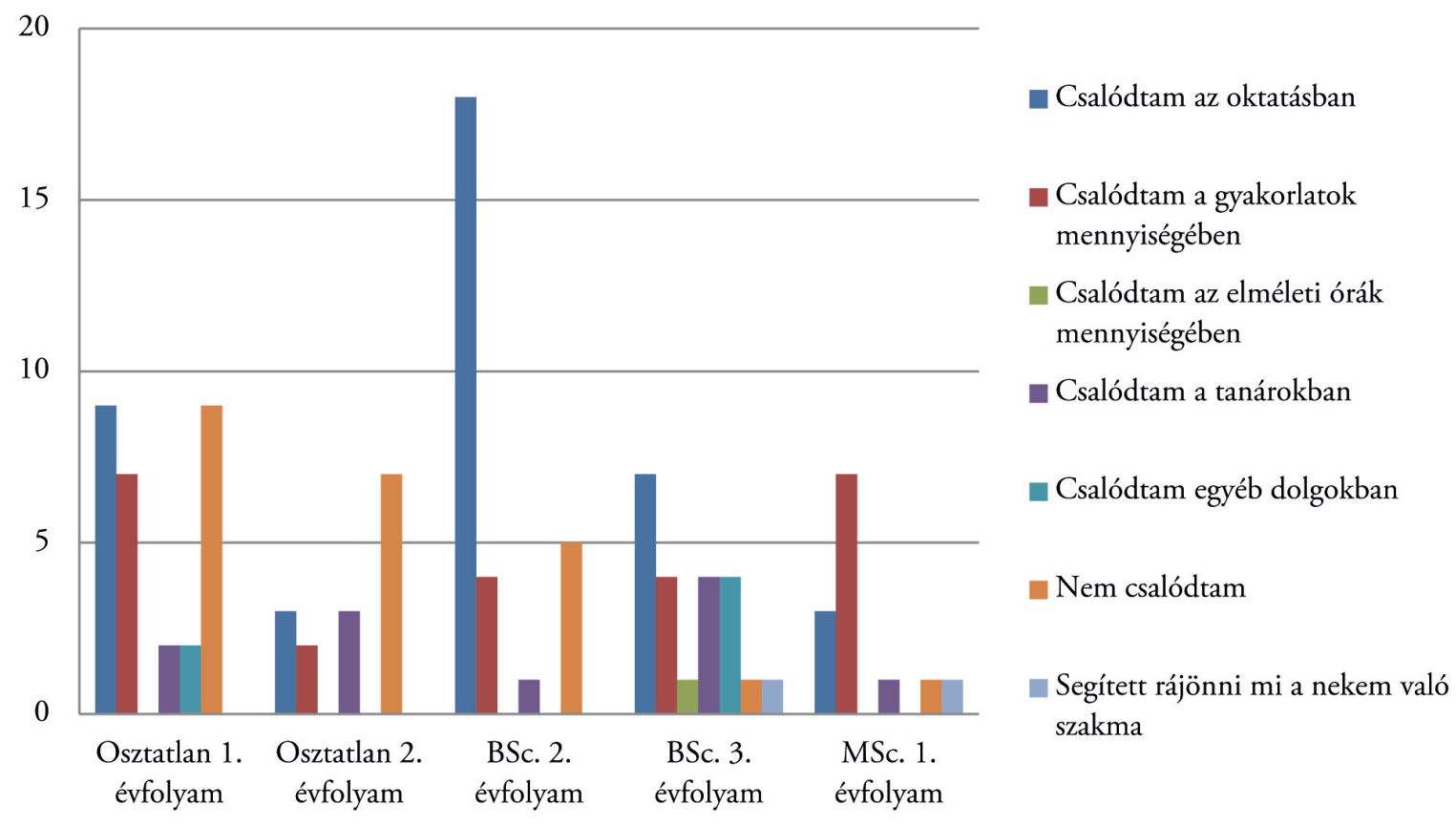

\section{4. ábra: Évfolyamok képzéssel kapcsolatos elégedettsége}

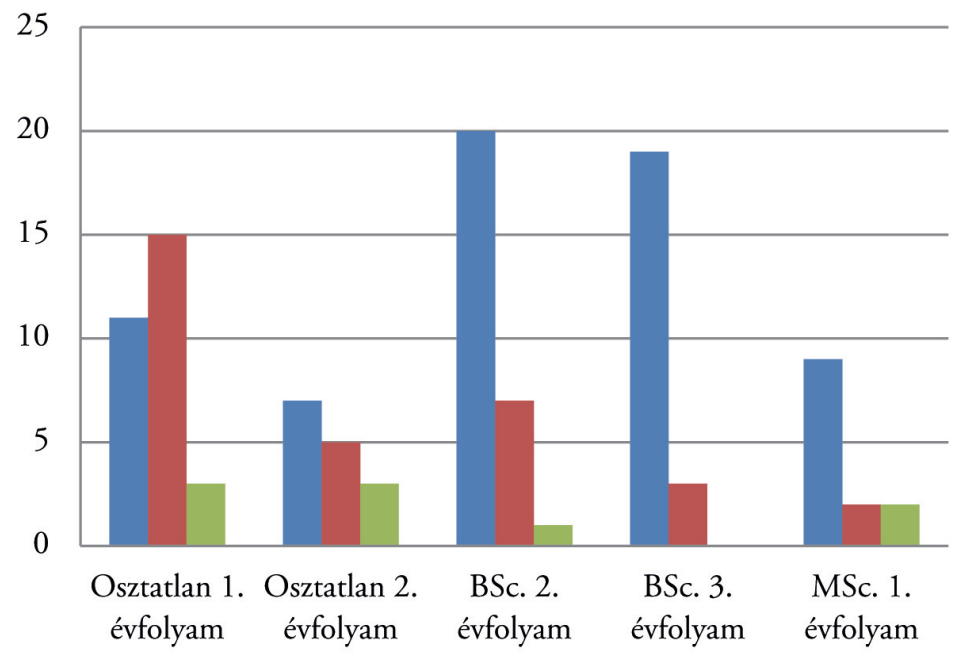

— Nem azt kaptam amit vártam

Azt kaptam amit vártam

- Többet kaptam mint amit vártam

\section{5. ábra: Évfolyamok intézmény megítélése}


A képzési formák között is megfigyelhetők szignifikáns eltérések, mind az elégedettség mértéke $(U=1029,5 ; Z=-2,346 ; p=0,019)$, mind a képző intézmény megítélése $(U=891 ; Z=-3,648 ; p<0,001)$ tekintetében. Az osztott képzési rendszerben lévő hallgatók összességében elégedetlenebbek mind az oktatással, mind a gyakorlatok és az elméleti órák számával (lásd. 6. ábra). Az intézmény kapcsán elmondható, hogy az osztott képzésben tanulók a leginkább elégedetlenek, mert nem azt kapták, amit vártak, míg az osztatlan képzésen megoszlanak a vélemények (lásd. 7. ábra).

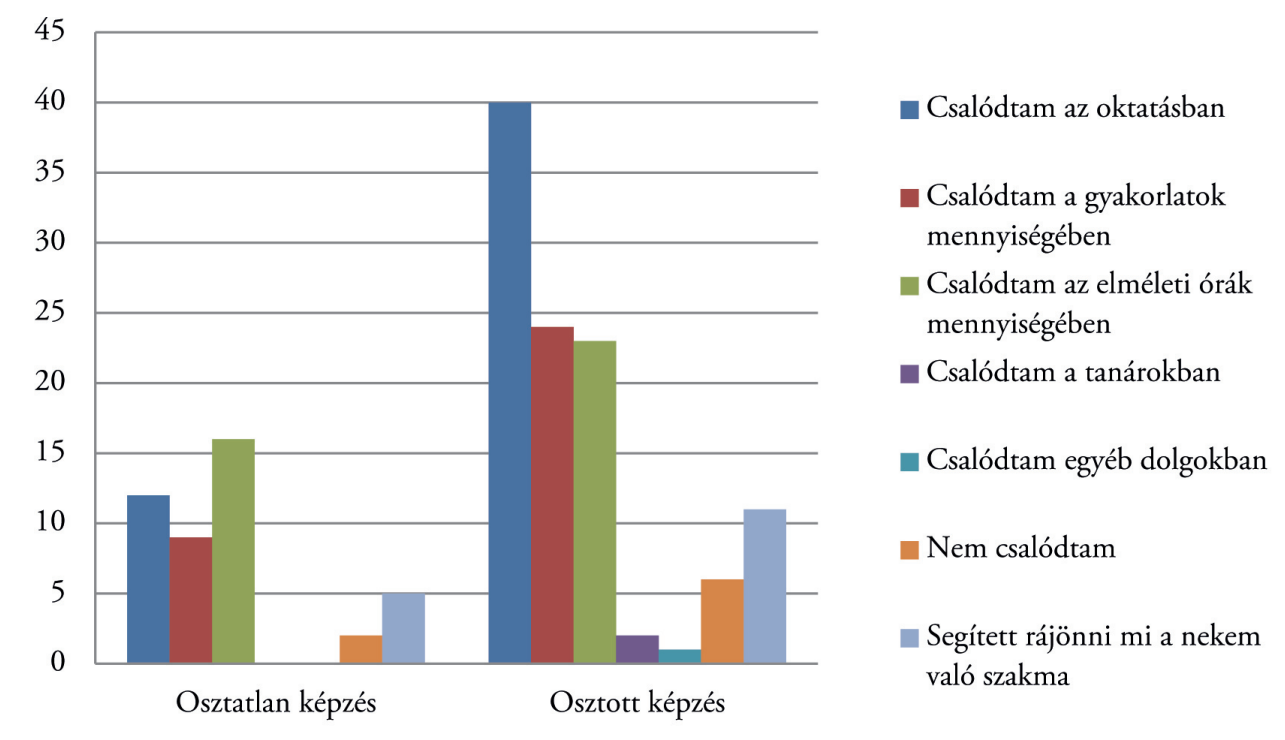

\section{6. ábra: A különböző képzési formákban tanuló hallgatók képzéssel való elégedettsége}

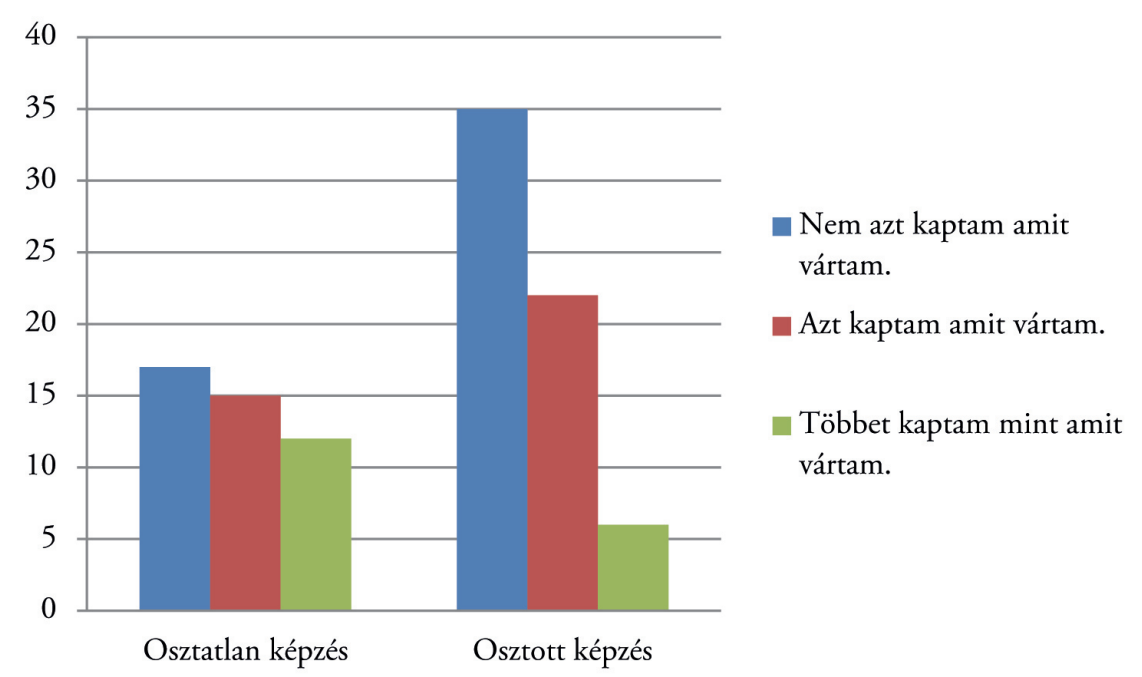

\section{7. ábra: A képző intézmény megítélése}

A harmadik hipotézis teszteléséhez a tanári pályáról kialakult képet és a jövőbeli terveket vizsgáltuk meg. A hallgatók 77,6 \%-a szeretne tanárként és mellette edzőként elhelyezkedni (83 fö), 2,8\% csak a tanári pályát tartja szem előtt (3 fö), $15 \%$ tanári végzettséggel ugyan, de nem a köznevelésben szeretne dolgozni (16 fö), 4,7\% pedig teljesen már állásra vágyik (5 fó) a végzést követően. Aki szívesen dolgozna tanárként, arról elmondható, hogy több évig képzeli el magát a pályán. A hallgatók majdnem fele akár több mint 20 évig is dolgozna tanárként (lásd. 8. ábra). A tanári pálya megítélése kapcsán a hallgatók 65,4 \%-ának változott a véleménye (70 fó), ebből 48,6 \% negatívabban értékeli azt (52 fö). 

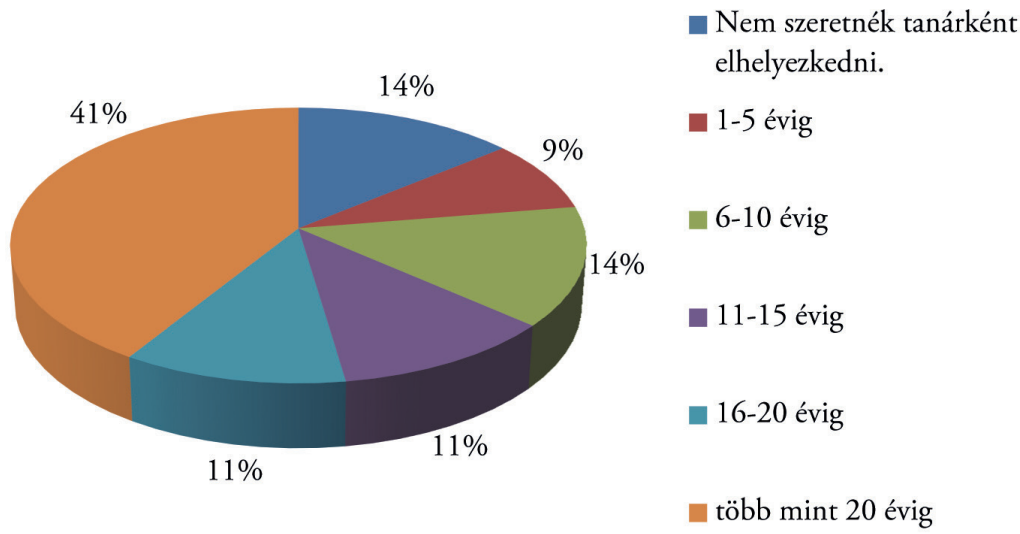

\section{8. ábra: A hallgatók tanári pályán eltölteni kívánt éveinek száma}

Az évfolyamok között megfigyelhetők szignifikáns különbségek a tanári pályán eltölteni kívánt idő $\left(\chi^{2}(4)=12,415 ; \mathrm{p}=0,015\right)$, valamint a tanári pálya megítélése $\left(\chi^{2}(4)=12,104 ; \mathrm{p}=0,017\right)$ kapcsán is. Az osztatlan 1. évfolyamosok szeretnének a legtovább tanári pályán dolgozni. A BSc 2. évfolyam a legmegosztottabb e kérdést illetően, többen egyáltalán nem szeretnének tanárként dolgozni, de itt a második legmagasabb az akár 20 évig is a tanári pályát választók száma (lásd. 9. ábra). A tanári pálya megítélése a BSc 2. évfolyamon a legnegatívabb, míg pozitív értékelést az osztatlan 1. és 2. évfolyamosok adtak leginkább (lásd. 10. ábra).

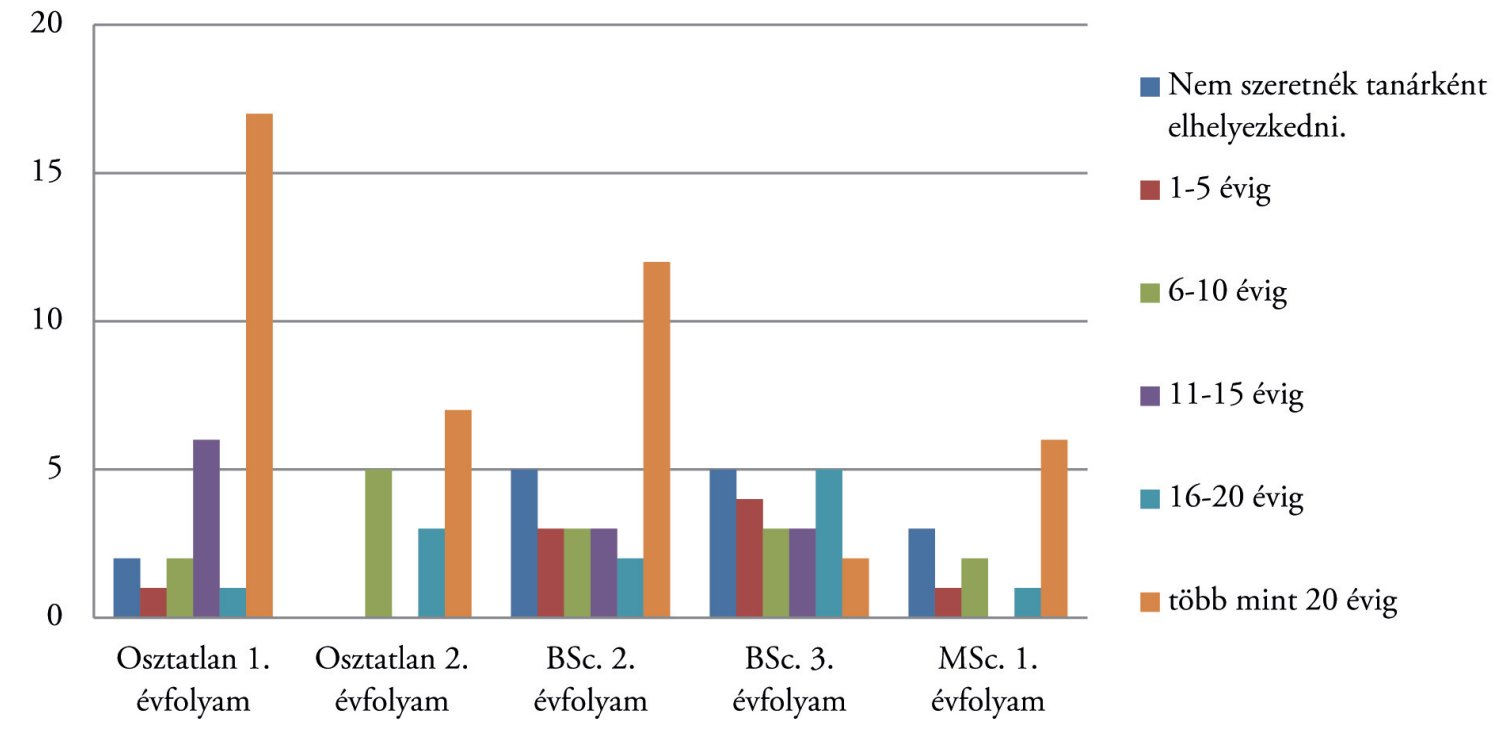

9. ábra: Évfolyamok közötti különbségek a tanári pályán eltölteni kívánt évek számát illetően

A képzési formák között is szignifikáns különbségek mutathatók ki mind a tanári pályán eltölteni kívánt idő ( $U=947 ; Z=-2,895 ; p=0,004)$, mind a tanári pálya megítélése $(U=1064,5 ; Z=-2,222$; $\mathrm{p}=0,026)$ kapcsán. Az osztatlan képzésben résztvevők nagyobb számban szeretnének több mint 20 évig tanárként dolgozni, mint az osztott képzésben lévők. Az osztott képzésből többen egyáltalán nem akarnak tanárként elhelyezkedni, és jobban megoszlik a tanárként eltölteni kívánt munkaévek száma is (lásd. 11. ábra). A tanári pálya megítélése az osztott képzésen tanulók esetében sokkal negatívabb, míg az osztatlan képzésen lévő hallgatók között többen pozitívabb képet alkotnak a pályájukról, mint előtte (lásd. 12. ábra). 


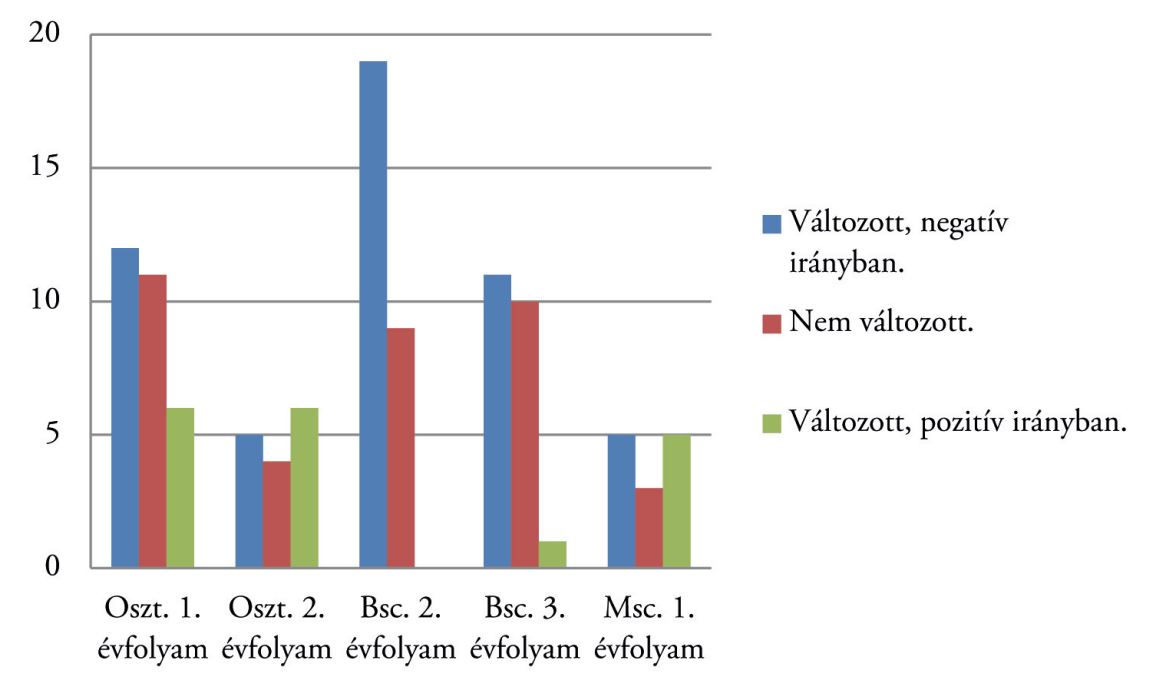

10. ábra: A tanári pálya megítélésének változása, a különböző évfolyamok véleményének tükrében

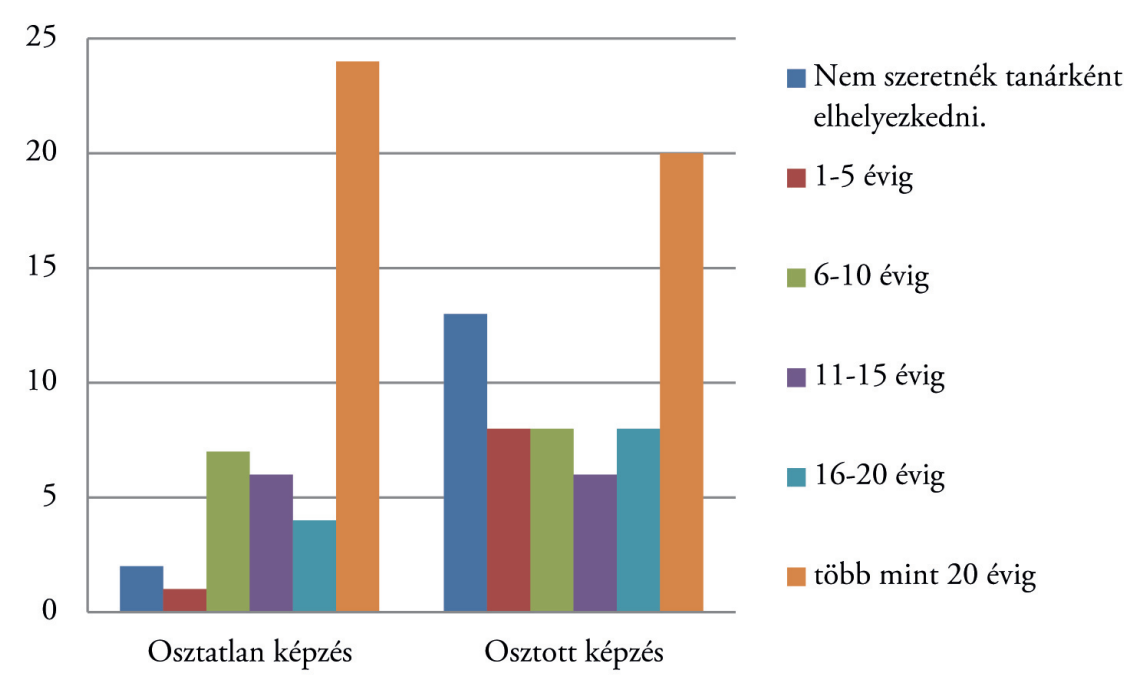

11. ábra: Képzési formák közötti különbségek a tanári pályán eltölteni kívánt évek száma alapján

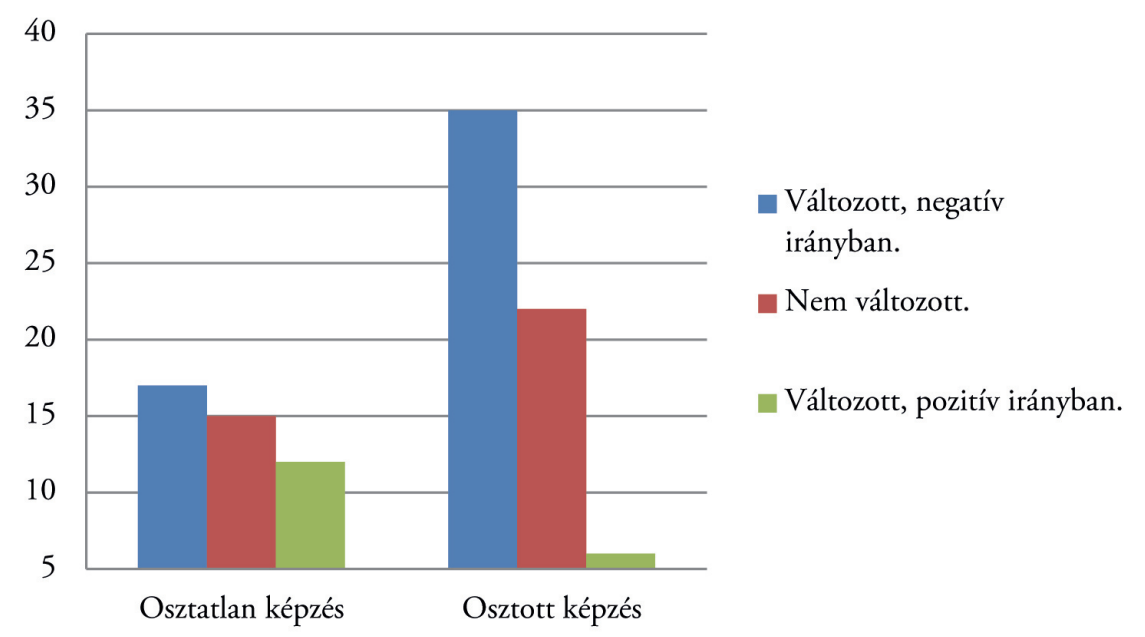

12. ábra: Képzési formák közötti különbségek a tanári pálya megítélésével kapcsolatban 
Megvizsgáltuk az egyes kérdések közti korrelációs kapcsolatokat is, mivel a leírt eredmények öszszefügghetnek egymással. A tanári pályán eltölteni kívánt idő erős, negatív kapcsolatban áll a jövőbeli tervekkel, míg erős, pozitív kapcsolat figyelhető meg a tanári pálya megítélése és a képzéssel való elégedettség, a tanári pálya és az intézmény megítélése, valamint a képzéssel való elégedettség és az intézmény megítélése tekintetében (lásd. 1. táblázat).

\section{1. táblázat: Az egyes tételek közti korrelációs kapcsolatok, szürkével kiemelve a szignifikáns értékek}

\begin{tabular}{|c|c|c|c|c|c|}
\hline & $\begin{array}{c}\text { Tanári pályán } \\
\text { eltölteni } \\
\text { kívánt idő }\end{array}$ & $\begin{array}{l}\text { Jövőbeli } \\
\text { tervek }\end{array}$ & $\begin{array}{l}\text { Tanári pálya } \\
\text { megítélése }\end{array}$ & $\begin{array}{l}\text { Képzéssel } \\
\text { való } \\
\text { elégedettség }\end{array}$ & $\begin{array}{l}\text { Intézmény } \\
\text { megítélése }\end{array}$ \\
\hline Jelentkezési motiváció & $\begin{array}{l}-, 043 \\
, 660\end{array}$ & $\begin{array}{l}, 134 \\
, 168\end{array}$ & $\begin{array}{l}-, 117 \\
, 229\end{array}$ & $\begin{array}{c}-, 174 \\
, 072\end{array}$ & $\begin{array}{l}-, 046 \\
, 641\end{array}$ \\
\hline Tanári pályán eltöltött idő & & $\begin{array}{c}-, 559\left(^{* *}\right) \\
, 000\end{array}$ & $\begin{array}{l}, 143 \\
, 141\end{array}$ & $\begin{array}{l}, 083 \\
, 393\end{array}$ & $\begin{array}{l}, 106 \\
, 277\end{array}$ \\
\hline Jövőbeli tervek & & & $\begin{array}{l}-, 176 \\
, 071 \\
\end{array}$ & $\begin{array}{c}-, 016 \\
, 868 \\
\end{array}$ & $\begin{array}{c}-, 044 \\
, 651 \\
\end{array}$ \\
\hline Tanári pálya megítélése & & & & $\begin{array}{c}, 504(* *) \\
, 000\end{array}$ & $\begin{array}{c}, 613(* *) \\
, 000\end{array}$ \\
\hline Képzéssel való elégedettség & & & & & $\begin{array}{c}, 429\left(^{* *}\right) \\
, 000\end{array}$ \\
\hline
\end{tabular}

\section{Megbeszélés}

Vizsgálatunk célja testnevelő tanárjelöltek pályaválasztással kapcsolatos attitűdjeinek vizsgálata volt. A hipotéziseinket részben sikerült alátámasztani, és minden vizsgált tényező tekintetében számottevő különbségeket tapasztaltunk a képzési rendszerek és évfolyamok között.

Elsőként azt feltételeztük, hogy a tanári hivatástudat kevésbé jelentős motivációs tényező a tanárjelöltek pályaválasztásában. Eredményeink alapján megállapítható, hogy az egész mintát tekintve a sportolás iránti szeretet a legerőteljesebb motiváció a választás során, mely kiemelkedően magas az osztott képzésben résztvevő hallgatók között.

Ennek tudatában jól magyarázható a második hipotézisünk eredménye, mely szerint a vizsgálatban részt vevő hallgatók közel 62\%-a csalódott a képzésben. Ök nem azt kapták, amit vártak, szerintük a képzés gyakorlati része aránytalanul kevesebb, mint az elméleti rész. A képzési rendszert áttekintve azt tapasztaljuk, hogy az elméleti és gyakorlati órák aránya 50-50\%. A vélemény megformálása a gyakorlati órák tartalmának szubjektív megtapasztalásából fakadhat. A gyakorlati órák tartalmi hangsúlya az „edzés jellegü” képességfejlesztésen és a sportági sajátélmény megszerzésén van, holott inkább a „hogyan kell oktatni” szakmai és pedagógiai módszereken kellene alapulnia. A BSc másodéves hallgatók nagyobb mérvű csalódottsága abból fakadhat, - amely egyébként torzító hatást fejt ki a végső eredményre - hogy a másodéves képzés megkezdése után dönthettek arról, hogy folytatják-e tovább testnevelő-edzői szakon a tanulmányaikat. A tanárképzési rendszer átalakítása miatt, ez az alapképzési forma biztosította a tanulmányok folytatását szakedzői MSc szakon. A másik opció az osztatlan tanárképzésbe történő bekapcsolódás a hiányzó kreditek pótlásával. Ez a váratlan döntési helyzet befolyásolhatta negatív irányba a képzésről és a képzőhelyről kialakult véleményüket. A klasszikus tanár és edző (testnevelö-edző) képzési folyamat a jelen képzési struktúrában nem megvalósítható. Jelenleg az edzői, és a testnevelő tanári szakma a képzést tekintve teljesen elváltak egymástól. Míg előbbi a sporttudományok, addig utóbbi a pedagógia tudományterületébe sorolható.

Harmadik hipotézisünk a végzést követő 
tervekkel kapcsolatban az volt, hogy a hallgatók többsége nem pedagóguspályán szeretne elhelyezkedni. Ezzel szemben a vizsgált hallgatók közel 78\%-a kíván a végzést követően testnevelő tanárként és edzőként is egyaránt dolgozni. Ezt a szempontot mindenképpen érdemes lenne figyelembe venni a következő képzési rendszerek mintatanterveinek összeállítása során. Azoknak a hallgatóknak több mint a fele (52\%), akik tanárként is el tudják képzelni magukat, több mint 10 évig maradna a pályán. A képzési formák összehasonlításakor azt látjuk, hogy az osztatlan szakra járók elkötelezettebbek a tanári pálya iránt az 1 . és 2 . évfolyamon, hiszen többségük 20 évnél tovább tervez a pályán maradni.

Falus (2004) szerint a pedagógussá válás három szakasza közül az első, a képzés előtti élmények erőteljes hatást gyakorolnak a pályaválasztási motivációra. A négy éves kortól rendszeresen sportolók számára is jelentős motiváló ereje van az egyén számára a megszerzett mozgásos kompetenciának és a versenysikereken keresztül felépített önbizalomnak. Természetesen kívülről is nagyon sok támogatást kapnak ezek a sportolók a szülők és az edzők részéről. Így nagyon sok esetben egyértelmű a választás a középiskolát követően. Felsőfokú oktatási intézménybe bekerülni nem jelenthet gondot az edzésben lévő, kiválóan teljesítő versenyzőknek, akik sokszor nemzetközi szintű eredményeikkel plusz pontokat tudnak szerezni. Az első csalódás a képzésbe való bekerülés után éri a sportolókat, akik számára a jól megszokott edzések helyett, egy másik szerep tanulása kezdődik meg. Ez a szerepváltás hozza létre véleményünk szerint azt a disszonanciát, amely a képzéssel és a képző intézménnyel kapcsolatos negatív attitüdhöz vezet. A képzés vége felé ez a (kognitív) disszonancia (Festinger, 2000) a képzésben maradás érdekében csökkeni fog. A disszonanciaredukció a legtöbb esetben tudattalan pszichológiai folyamatokon keresztül következik be. Amennyiben a feszültséget tudatosan nem sikerül kontrollálni, úgy az az egyénre jellemző éretlen (maladaptív) vagy érett (adaptív) énvédő elhárító mechanizmusok révén sajátos döntésekhez és ezen keresztül sajátságos eredményekhez vezet. A halogatástól kezdve a szak- vagy intézményváltáson keresztül a tanulmányok megszakításáig több olyan megoldás megjelenhet, amely egy pillanatnyi ideig enyhíti a feszültséget, de nem kínál adaptív megoldásokat. Pozitív kimenet esetében kedvező irányú attitüdváltozás következik be, melynek következménye pl. a motivációs bázis megváltozása. Ezt a megállapítást látszik alátámasztani Spittle és Spittle (2014) eredménye is miszerint azok a tanítóképzős hallgatók, akik testnevelés és sport műveltségterületet választanak évfolyamonként eltérő motivációval rendelkeznek.

Vizsgálatunk néhány korlátját is érdemes figyelembe venni az eredmények értékelésekor. A vizsgált minta könnyen elérhető, az adott intézményre vonatkozóan reprezentatív, de nem alkalmas a populációra igaz, általános következtetések levonására. Az online kérdőív gyakran alkalmazott és bevált módszertani megoldás, azonban az önbeszámolót befolyásolhatták kontextuális tényezők vagy a szociális megfelelés igénye, mint pl. a csoporthoz tartozás. Továbbá sztenderdizált kérdőívek alkalmazása lehetővé tette volna az eredmények nemzetközi szintű összehasonlítását.

Összességében elmondhatjuk, hogy keresztmetszeti vizsgálatunkban feltártuk a testnevelő tanár szakos hallgatók tanárképzéssel kapcsolatos attitűdjeit és összehasonlítottuk azokat a kétféle képzési rendszerben tanulók alapján. Az eredmények visszacsatolhatók a tanárképzésbe. A hallgatók értékrendszerének feltárása, önismeretük erősítése, a képzéssel kapcsolatos információk tudatosítása mind olyan feladatok, melyek segíthetik a sikeres pályaválasztást és később a pálya iránti elköteleződés kialakulását.

\section{Felhasznált irodalom}

1. Berliner, D. C. (2005). Szakértő tanárok viselkedésének leírása és teljesítményeik dokumentálása. Pedagógusképzés, 3(32), 71-92.

2. Brezsnyánszky, L. (2006). A maga vájta meder. Gondolatok a formálódó tanárképzésröl. Budapest, Magyarország: Gondolat Kiadó.

3. Chrappán, M. (2010). Pályaelégedettség és karriertervek a pedagógus képzettségü hallgatók körében. Educatio, 4, 268-286.

4. Dávid, J. (2005). Munkaerö piaci igények és a szakképzési rendszer közelitése. Budapest, Magyarország: Nemzeti Felnőttképzési Intézet.

5. Dudás, M. (2005). A tanárképzésbe belépő hallgatók nézeteinek feltárási lehetőségei. Pedagógusképzés, 2(31), 23-46.

6. Falus, I. (2002). Szakdolgozat a pedagógiai képzésben. Iskolakultuira, 1, 73-78.

7. Falus, I. (2004). A pedagógussá válás 
folyamata. Educatio, 3, 359-374.

8. Falus, I. (2006). A tanári tevékenység és a pedagógusképzés új útjai. Budapest, Magyarország: Gondolat Kiadó.

9. Festinger, L. (2000) A kognitiv disszonancia elmélete. Budapest, Osiris Kiadó.

10. Huberman, A. M., Groundauer, M. \& Marti, J. (1993). The lives of teachers. New York, NY: Teachers College Press.

11. Kenderfi, M. (2011). Pályaorientáció. Budapest, Magyarország: Szent István Egyetem.

12. Kocsis, M. (2003). A tanárképzés megitélése. Pécs, Magyarország: Iskolakultúra.

13. Laczkovich, M. (2009). Bologna és a tanárképzés. Fizikai Szemle, 6, 218-220.

14. Lukács, P. (2002). A pedagógusképzés megújitásához I. Budapest, Magyarország: Oktatáskutató Intézet.

15. Lukács, P. (2004). A felsőoktatás expanziója. In Gábor, K. \& Jancsák, Cs. (Eds.): Iffúsági korszakváltás - ifjúság az új évezredben (pp. 19-25). Szeged, Magyarország: Belvedere Meridionale.

16. Nagy, M. (2001). A tanári pálya választása. In Papp, J. (Ed.): A tanári pálya (pp. 103-122). Debrecen, Magyarország: Kossuth Egyetemi Kiadó.

17. Nagy, M. (2004). Pályakezdés, mint a pedagógusképzés középső fázisa. Educatio, 3, 375-390.

18. Rókusfalvy, P. (1969). Pályaválasztás, pályaválasztási érettség. Budapest, Magyarország: Tankönyvkiadó.

19. Sallai, É. (2001). Tanulható-e a pedagógus mesterség? Veszprém, Magyarország: Veszprémi Egyetemi Kiadó.
20. Sági, M. \& Varga, J. (2011). Pedagógusok. In Balázs, É., Kocsis, M. \& Vágó, I. (Eds.): Jelentés a magyar közoktatásról 2010. (pp. 295325). Budapest, Magyarország: OFI.

21. Simon, K. (2006). A tanári pályát választó hallgatók néhány, pályamotivációval összefüggő sajátossága. Pedagógusképzés, 4(33), 5-16.

22. Spittle, S. \& Spittle, M. (2014). The reasons and motivation for pre-service teachers choosing to specialise in primary physical education teacher education. Australian Journal of Teacher Education, 39(5), 1-25. http:// dx.doi.org/ 10.14221/ajte.2014v39n5.5

23. Szilágyi, K. (1993). A tanácsadási elméletek. Gödöllő, Magyarország: GATE Tanárképző Intézet.

24. Szilágyi, K. (1997). Az egyéni tanácsadás. Gödöllő, Magyarország: Gödöllői Agrártudományi Egyetem Tanárképző Intézet.

25. Szilágyi, K. (2000). Munka-pályatanácsadás mint professzió. Budapest, Magyarország: Kollégium $\mathrm{Kft}$.

26. Szemes, Á. (2016). A szakirány választását befolyásoló háttértényezők és munkaérték preferenciák összehasonlító vizsgálata pszichológia mesterszakosok körében. Impulzus, 3, 1-17.

27. Varga, J. (2007). Kiböl lesz ma tanár? A tanári pálya választásának empirikus elemzése. Közgazdasági Szemle, 4, 609-627.

28. Völgyesy, P. (1976). A pályaválasztási döntés elökészitése. Budapest, Magyarország: Tankönyvkiadó. 